\title{
Pendekatan Dengan Cuckoo Optimization Algorithm Untuk Solusi Permasalahan Economic Emission Dispatch
}

\author{
Agil Dwijatmoko Rahmatullah, Rony Seto Wibowo dan Daniar Fahmi \\ Jurusan Teknik Elektro, Fakultas Teknologi Industri, Institut Teknologi Sepuluh Nopember (ITS) \\ Jl. Arief Rahman Hakim, Surabaya 60111 \\ e-mail: ronyseto@ee.its.ac.id, daniarfahmi@ee.its.ac.id
}

\begin{abstract}
Abstak--Economic Dispatch adalah upaya untuk meminimalkan biaya operasi unit pembangkit dengan tetap memperhatikan batasan teknis dari masing-masing unit pembangkit, harga bahan bakar, biaya pemeliharaan dan lain sebagainya. Di sisi lain, unit pembangkit termal menggunakan bahan bakar fosil sebagai bahan bakar boiler untuk membangkitkan energi listrik, sehingga sisa hasil pembakaran dari unit pembangkit ini menghasilkan emisi gas buang yang menyebabkan polusi serta mencemari lingkungan. Melalui dua permasalahan tersebut metode optimasi algoritma cuckoo yang diadaptasi dari cara burung cuckoo dalam berkembang biak, sarang yang menghasilkan generasi baru cuckoo direpresentasikan sebagai solusi baru untuk permasalahan optimasi dalam meminimalkan biaya bahan bakar dan emisi gas buang. Hasil dari metode optimasi algoritma cuckoo, pada saat nilai pembobot seimbang yaitu 0,5 , untuk fungsi biaya bahan bakar didapatkan 18940,40 dengan pengurangan biaya sebesar 1745,3 dan untuk fungsi emisi didapatka 839,94 dengan pengurangan emisi sebesar 187,35 .
\end{abstract}

Kata Kunci--Cuckoo Optimization Algorithm, Economic Emission, Economic Dispatch.

\section{PENDAHULUAN}

$\mathrm{O}$ PTIMASI dispatch ekonomi klasik (ED) telah menjadi subjek berbagai makalah penelitian sebagai salah satu masalah utama adalah pengoperasian secara ekonomis. Karena pertimbangan lingkungan baru-baru ini, tujuan dari Economic Dispatch Masalah tidak dapat dibatasi hanya meminimalkan biaya bahan bakar saja namun juga emisi gas [1]. Meningkatnya permintaan energi listrik menyebabkan meningkatnya pula listrik yang harus dihasilkan sehingga penambahan unit pembangkitpun juga harus dikembangkankan [2]. Energi listrik yang dihasilkan menggunakan berbagai sumber konvensional dan terbarukan termasuk didalamnya air, nuklir, angin, surya, dan energi kinematik pasang surut gelombang air laut. Salah satu bagian utama dari energi listrik di hasilkan dari unit termal yang menggunakan bahan bakar fosil seperti gas, minyak, batu bara [3] [4].

Tujuan dari economic emission Dispatch ialah bagaimana miminimalkan biaya operasi masing- masing unit pembangkit serta jumlah emisi gas buang dari masing-masing unit pembangkit termal namun dengan tetap memperhatikan batasan teknis masing masing ]unit pembangkit. Pada Penelitian ini akan diusulkan Cuckoo Optimization Algorthm untuk menyelesaikan permasalahan Economic-emission. Sehingga diperoleh pembangkitan optimal, ekonomis, dan mampu meminimalkan jumlah emisi yang dihasilkan unit pembangkit [5].

\section{ECONOMIC EMISSION DISPATCH}

Tujuan dari Economic Emission dispacth meminimalkan biaya pembangkitan khususnya bahan bakar namun juga miminimalkan emisi gas buang dengan menentukan besarnya pembangkitan masing-masing unit pembangkit .

\section{A. Fungsi biaya}

Objektif dalam permasalahan EED (Economic Emission Dispatch) adalah fungsi biaya pembangkitan. Berikut persamaan yang digunakan :

$$
F c(P)=\sum_{i=1} N\left(\alpha i+b i P i+C i P i^{2}\right)
$$

Keterangan:

$a_{i,} b_{i, C i}:$ Cost function

$\mathrm{Pi} \quad$ :output daya dari masing-masing pembangkit dalam MW

\section{B. Fungsi Emisi}

Fungsi objektif kedua yaitu fungsi emisi pada masingmasing unit dengan satuan gram tiap jamnya. Berikut persamaan fungsi emisi:

Keterangan:

$$
F C(P)=\sum_{i=1} N\left(d i+e i P i+f i P i^{2}\right)
$$

$d_{i}, e_{i} f \quad$ :Emission function

\section{Pembatasan (constrain)}

Dalam menyelesaikan Economic Emission terdapat beberapa batasan (constrain) .

\section{Keseimbangan Daya}

Daya total pembangkitan harus sesuai dengan daya total beban, sesuai dengan persamaan 3 berikut ini:

$$
\sum P i=P d
$$

Keterangan :

$\mathrm{Pd}:$ Total Daya
$\mathrm{Pi}:$ daya yang dibangkitkan masing - masing
pembangkit

\section{Batas Kapasitas Pembangkitan}

Untuk menstabilkan sistem pembangkitan maka masing masing pembangkitan dibatasi oleh pembangkitan maksimal dan pembangkitan minimal masing-masing unitnya. Seperti yang ditunjukan oleh persamaan 4 berikut ini : 


$$
P_{G i} \min \leq P_{G i} \leq P_{G i} \max
$$

Keterangan:

$P_{G i} \min :$ Daya pembangkitan minimum masing-masing unit Pembangkit

$P_{G i} \max \quad$ : Daya pembangkitan maksimum masing-masing unit pembangkit

Daya pembangkitan tidak boleh melebihi batas dari ramp limit untuk masing masing unit.

$$
\operatorname{Max}\left(\mathrm{P}_{\mathrm{i} \text { min }}, \mathrm{P}_{\mathrm{i}}^{\mathrm{t}-1}-\mathrm{ramp}\right) \leq, \mathrm{P}_{\mathrm{i}}^{\mathrm{t}-1} \leq \min \left(\mathrm{P}_{\mathrm{i} \min ,} \mathrm{P}_{\mathrm{i}}^{\mathrm{t}-1}+\operatorname{ramp}\right)
$$

Dengan adanya ramp constrain maka kapasitas constraint pembangkitan jam ke-1 akan berubah menjadi maksimum dan minimum.

Untuk persamaan maksimum,

$$
\mathrm{P}_{\mathrm{i} \min ,}=\max \left(\mathrm{P}_{\mathrm{i} \min ,} \mathrm{P}_{\mathrm{i}}^{\mathrm{t}-1}-\mathrm{ramp}\right)
$$

Untuk persamaan minimum,

$$
\mathrm{P}_{\mathrm{i} \min ,}=\max \left(\mathrm{P}_{\mathrm{i} \min ,} \mathrm{P}_{\mathrm{i}}^{\mathrm{t}-1}+\mathrm{ramp}\right)
$$

\section{Weight sum method}

Weight sum method merupakan salah satu teknik paling sederhana untuk penyelesaian optimasi multi objektif yang menggabungkan beberapa fungsi objektif menjadi satu kesatuan, dengan cara perkalian masing-masing fungsi obyektif dengan koefisien pembobot weight masing-masing fungsi objektif.

Pada Penelitian ini ada dua fungsi objektif yang digunakan untuk meminimalkan biaya bahan bakar dan untuk meminimalkan emisi $\mathrm{NO}_{2}$. berikut adalah persamaan yang digunakan:

$$
F=W c \cdot F c t+W s \cdot F e t
$$

Dimana :

F : fungsi tujuan

Fct :Total biaya bahan bakar masing pembangkitan dalam sistem (Rupiah)

Fet :Total emisi bahan bakar masing pembangkitan dalam sistem (Gram)

Wc : Nilai pembobot untuk fungsi biaya bahan bakar

Ws : nilai pembobot untuk fungsi emisi bahan bakar

Jumlah total dari masing - masing koefiesien pembobot yaitu satu, besarnya nilai koefisien menunjukkan prioritas.

\section{PENERAPAN CUCKOO OPTIMIZATION ALGORITHM PADA ECONOMIC EMISSION DISPATCH}

Jumlah populasi nest (n) sarang yang akan dipilih burung cuckoo untuk meletakkan telur mewakili jumlah daya output masing-masing unit yang direpresentasikan.

$n e s t(i,:)=L b+(U b-L b) . * \operatorname{rand}(\operatorname{size}(L b))$

Keterangan:

Ub yaitu batas bawah dan Lb batas atas pembangkitan tiap unit
Untuk langkah selanjutnya membangkitkan generasi baru menggunakan jalur levy flight. Levy fight adalah jalur burung cuckoo untuk menemukan sarang baru. Solusi baru dihitung berdasakan pada inisialisasi sebelumnya atau sejumlah sarang sebelumnya yang kemudian dipilih lagi jalur cuckoo untuk pemilihan sejumlah sarang yang baru.

$$
\mathrm{X}_{\mathrm{I}}^{\text {new }}=\text { Xbest }_{\mathrm{i}}+\alpha \mathrm{x} \text { rand } 2 \times \Lambda \mathrm{X}_{\mathrm{i}}^{\text {new }}
$$

Kemungkinan burung lain menemukan telur cuckoo pada sarang burungnya untuk memilih meninggalkan sarang dan membangun sarang baru atau menendang keluar telur burung cuckoo juga merupakan solusi baru kemungkinan ini direpresentasikan $\mathrm{Pa}$, berikut adalah persamaan yang digunakan:

$$
\mathrm{X}_{\mathrm{I}}{ }^{\mathrm{dis}}=\mathrm{Xbest}_{\mathrm{i}}+\mathrm{K} \times \Lambda \mathrm{X}_{\mathrm{i}}^{\mathrm{dis}}
$$

Dimana $\mathrm{K}$ adalah koefisien update yang ditentukan oleh $\mathrm{Pa}$

Jika sarang random yang dipih kurang dari nilai kemngkinan maka nilai $\mathrm{K}$ adalah satu artinya faktor kemungkinan besar mendapat kan solusi baru disimpan begitu juga sebaliknya.

\section{HASIL DAN SIMULASI}

Data sistem yang digunakan pada simulasi ini menggunakan sistem pembangkit interkoneksi Jawa-Bali pada jaringan transmisi $500 \mathrm{kV}$. Sistem ini terdiri dari 8 genarator dengan 25 sistem bus. Jenis pembangkit pada sistem ini yaitu termal dan hidro, dimana terdiri dari 6 pembangkit jenis termal dan 2 pembangkit jenis hidro. Untuk lebih jelas, Single Line Diagram pembangkit interkoneksi Jawa-Bali dapat dilihat pada Gambar 1.

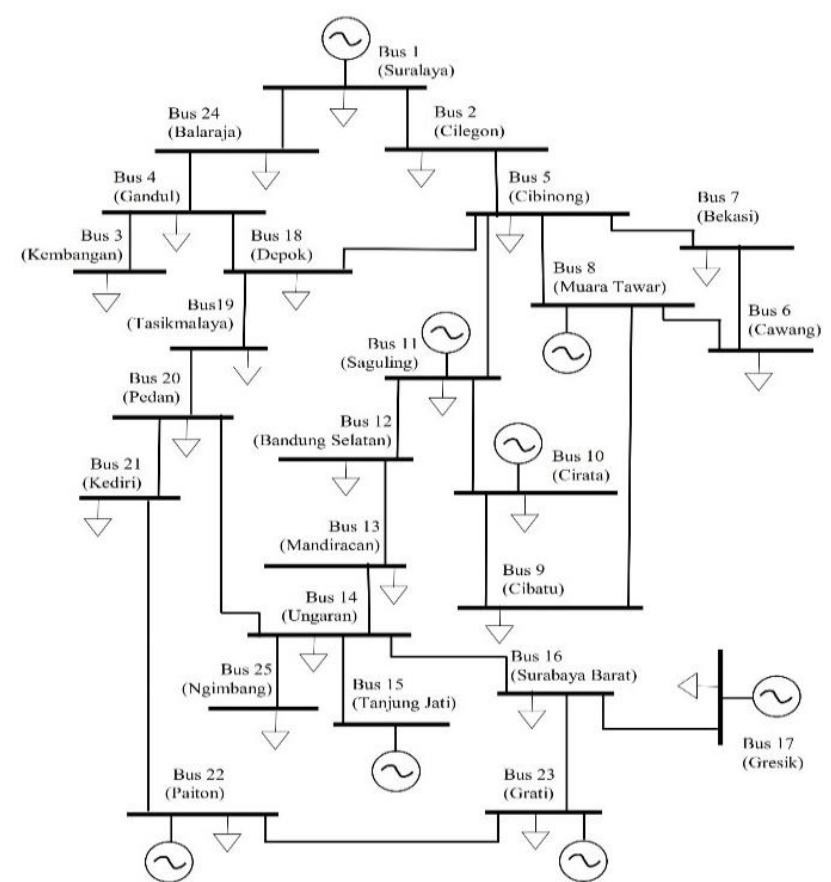

Gambar 1. Single Line Diagram sistem pembangkit interkoneksi Jawa-Bal $500 \mathrm{kV}$

Untuk data fungsi pembiayaan pembangkitan pada sistem pembangkit interkoneksi Jawa-Bali $500 \mathrm{kV}$ dapat dilihat pada Tabel 1 . 
Tabel 1.

Fungsi biaya sistem pembangkit interkoneksi Jawa-Bali

\begin{tabular}{crrrrr}
\hline \hline $\begin{array}{c}\text { Unit } \\
\text { Pembangkit }\end{array}$ & \multicolumn{1}{c}{ Aungsi Biaya } & \multicolumn{1}{c}{ B } & $\begin{array}{r}\text { Pmin } \\
\text { (MW) }\end{array}$ & $\begin{array}{c}\text { Pmax } \\
\text { (MW) }\end{array}$ \\
\hline Suralaya & $44.455 .587,75$ & $391.059,27$ & -11.008 .313 & 1610 & 4200 \\
Muaratawar & $747.887 .239,80$ & $673.189,59$ & -5.565 .550 & 934 & 2308 \\
Cirata & 0 & 6.000 & 0 & 404 & 1008 \\
Saguling & 0 & 660 & 0 & 208 & 700 \\
Tanjung Jati & 192.669 .508 & $125.456,19$ & 35,80 & 848 & 2119 \\
Gresik & $78.152 .917,59$ & $459.705,07$ & 7,59 & 1149 & 2872 \\
Paiton & $17.209 .148,67$ & $382.129,48$ & $-19,37$ & 1080 & 2700 \\
Grati & $25.244 .481,54$ & $371.803,55$ & 8,09 & 360 & 900 \\
\hline \hline
\end{tabular}

Sedangkan untuk data fungsi emisi pembangkitan pada sistem pembangkit interkoneksi Jawa-Bali $500 \mathrm{kV}$ dapat dilihat pada Tabel 2 .

Tabel 2.

Fungsi emisi sistem pembangkit interkoneksi Jawa-Bali

\begin{tabular}{crrr}
\hline \hline \multirow{2}{*}{ Unit Pembangkit } & \multicolumn{3}{c}{ Fungsi Emisi } \\
& \multicolumn{1}{c}{ A } & B & \multicolumn{1}{c}{ C } \\
\hline Suralaya & $-6,53435$ & 232126,27 & 26388095,96 \\
Muaratawar & $-0,7737$ & 93584 & 62263614,5 \\
Cirata & 0 & 0 & 0 \\
Saguling & 0 & 0 & 0 \\
Tanjung Jati & 25,157815 & 8816,75 & 135397090,2 \\
Gresik & 1,62795 & 98632 & 16768083 \\
Paiton & $-13,266773$ & 261721,95 & 11786612,11 \\
Grati & 2,467 & 113442,5 & 7702435,5 \\
\hline \hline
\end{tabular}

Rekam data total daya beban pada sistem pembangkit interkoneksi Jawa-Bali diambil dalam empat waktu, yaitu pada pukul 18.00, 19.00, 20.00, dan 21.00. Data total beban pada tanggal 9 Juni 2014 dapat dilihat pada Tabel 3.

Tabel 3.

Total beban berdasarkan waktu pada pembangkit interkoneksi Jawa-Bali ( 9 Juni 2014)

\begin{tabular}{cc}
\hline \hline Pukul & Beban (MW) \\
\hline 18.00 & 13096 \\
19.00 & 13108 \\
20.00 & 12863 \\
21.00 & 12228 \\
\hline \hline
\end{tabular}

\section{A. Hubungan Biaya Bahan Bakar dan Emisi}

\section{Hubungan Biaya Bahan Bakar Dan Emisi Dengan} Menggunakan Metode Cuckoo Optimization Algorithm

Pada sub-bab ini, akan dijelaskan hasil simulasi untuk total biaya dan total emisi selama 4 jam dengan 5 kondisi yang berbeda yang disesuaikan dengan tingkat prioritas dari objek yang diminimalkan. Hasil simulasi untuk total biaya dan total emisi selama 4 jam dengan menggunakan metode Cuckoo Optimization Algorithm (COA) dapat dilihat pada Tabel 4.

Tabel 4.

Hasil Simulasi Total Biaya dan Total Emisi Selama 4 Jam Menggunakan Cuckoo Optimization Algorthm

\begin{tabular}{ccc}
\hline \hline Kondisi & Biaya (Rupiah/4jam) & Emisi NO $_{\mathbf{2}}(\boldsymbol{\%})$ \\
\hline 1 & 18.645 .856 .084 & 8.577 .297 .435 \\
2 & 18.824 .261 .922 & 8.489 .371 .514 \\
3 & 18.845 .619 .232 & 8.389 .904 .230 \\
4 & 18.940 .408 .685 & 7.961 .175 .761 \\
5 & 20.590 .911 .053 & 7.761 .934 .970 \\
\hline \hline
\end{tabular}

Dari tabel diatas, dapat dilihat pada kondisi pertama yang di pertimbangkan hanya biaya pembangkitan dengan total 18.645.856.084 $\mathrm{Rp} / 4 \mathrm{Jam}$ dan dengan total emisi 8.557.297.435 gram/4jam. Pada kondisi kedua yang diprioritaskan lebih adalah biaya pembangkitan dari pada emisi dengan total biaya pembangkitan 18.824.261.922 $\mathrm{Rp} / 4 \mathrm{jam}$ dan total emisi 8.489.371.514 gram/4jam .

Pada kondisi ketiga total biaya pembangkitan dan total emisi sama-sama diprioritaskan, keduanya memiliki bobot yang sama dengan total biaya pembangkitan sebesar nilai 18.845.619.232 Rp/4jam dan total emisi dengan total emisi sebesar 8.389.904.230 gram/4jam. Pada kondisi keempat nilai emisi lebih diprioritaskan untuk di minimalkan dari pada biaya pembangkitan dengan total biaya pembangkitan sebesar 18.940.408.685 Rp/4jam dan total emisi dengan total emisi sebesar 20.590.911.053 gram/4jam. Pada kondisi kelima nilai emisi paling diprioritaskan dan nilai pembangkitan tidak diperhitungkan sama sekali dengan total biaya pembangkitan sebesar $20.590 .911 .053 \mathrm{Rp} / 4 \mathrm{jam}$ dan total emisi dengan total emisi sebesar 7.761.934.970 gram $/ 4$ jam.

Sedangkan kurva yang dibentuk dari biaya dan bahan bakar $\mathrm{NO}_{2}$ pada masing masing kondisi tiap pembobotan yang berbeda-beda dapat dilihat pada Gambar 4.2. Grafik tersebut menunjukkan bahwa semakin kecil nilai prioritas pembobot untuk nilai biaya bahan bakar.

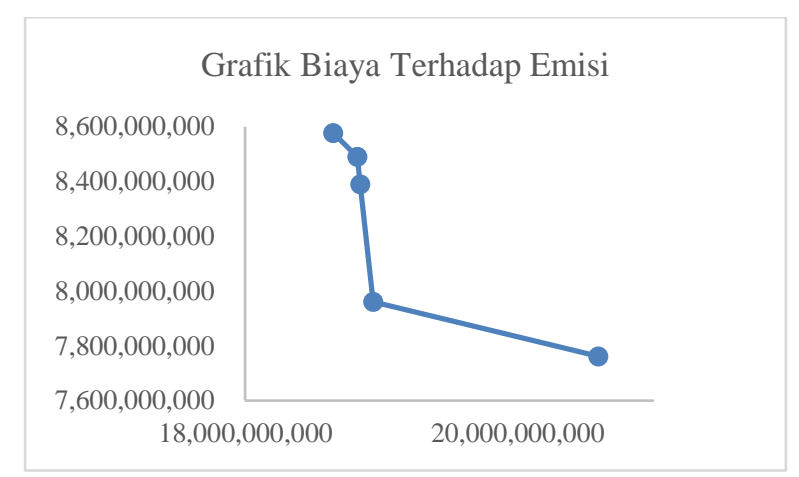

Gambar 2. Grafik Hasil Simulasi Biaya terhadap Emisi dengan Cuckoo Optimization Algorithm

2. Hubungan Biaya Bahan Bakar dan Emisi dengan Menggunakan Metode Firefly Algorthm

Berikut akan dijelaskan hasil simulasi untuk total biaya dan total emisi selama 4 jam dengan 5 kondisi yang berbeda yang disesuaikan dengan tingkat prioritas dari objek yang diminimalkan. Hasil simulasi untuk total biaya dan total emisi selama 4 jam dengan menggunakan metode Firefly Algorthm dapat dilihat pada Tabel 5.

Tabel 5.

Hasil Simulasi Total Biaya dan Total Emisi Selama 4 Jam Menggunakan Firefly Algorthm

\begin{tabular}{ccc}
\hline \hline Kondisi & Biaya (Rupiah/4jam) & Emisi NO $_{\mathbf{2}}(\boldsymbol{\%})$ \\
\hline 1 & $19.176 .042 .873,96$ & $8.677 .881 .402,00$ \\
2 & $19.233 .587 .743,28$ & $8.628 .485 .188,00$ \\
3 & $19.251 .392 .530,31$ & $8.523 .037 .291,00$ \\
4 & $19.539 .173 .481,41$ & $8.480 .266 .373,00$ \\
5 & $20.181 .370 .522,79$ & $8.294 .551 .135,00$ \\
\hline \hline
\end{tabular}

Dari tabel diatas, dapat dilihata pada kondisi pertama yang di pertimbangkan hanya biaya pembangkitan dengan 
total 19.176.042.873,96 Rp / 4 Jam dan dengan total emisi 8.677.881.402 gram/4jam. Pada kondisi kedua yang diprioritaskan lebih adalah biaya pembangkitan dari pada emisi dengan total biaya pembangkitan 19.233.587.743,28 $\mathrm{Rp} / 4 \mathrm{jam}$ dengan total emisi 8.628.485.188.

Pada kondisi ketiga total biaya pembangkitan dan total emisi sama-sama diprioritaskan, keduanya memiliki bobot yang sama dengan total biaya pembangkitan sebesar 19.251.392.530,31 Rp/4jam dan total emisi dengan total emisi sebesar 8.523.037.291 gram/4jam. Pada kondisi keempat nilai emisi lebih diprioritaskan untuk di minimalkan dari pada biaya pembangkitan dengan total biaya pembangkitan sebesar 19.253.173.481,41 Rp/4jam dan total emisi dengan total emisi sebesar 8.480.266.373 gram/4jam. Pada kondisi kelima nilai emisi paling diprioritaskan dan nilai pembangkitan tidak diperhitungkan sama sekali dengan total biaya pembangkitan sebesar 20.181.370.522,79 Rp/4jam dan total emisi dengan total emisi sebesar 8.294.551.135 gram/4jam.

Sedangkan untuk kurva yang dibentuk dari biaya dan bahan bakar $\mathrm{NO}_{2}$ pada masing masing kondisi tiap pembobotan masing-masing dengan metode Firefly Algorthm dapat dilihat pada Gambar 3. Berdasarkan hasil simulasi dan kurva biaya bahan bakar dan emisi, metode Cuckoo Optimization Algorithm cenderung lebih optimal.

\begin{tabular}{|l|}
\hline Grafik Biaya Tehapad Emisi \\
$8,700,000,000.00$ \\
$8,600,000,000.00$ \\
$8,500,000,000.00$ \\
$8,400,000,000.00$ \\
$8,300,000,000.00$ \\
$8,200,000,000.00$ \\
$19,000,000,000.00$ \\
$20,000,000,000.00$ \\
\hline
\end{tabular}

Gambar 3. Grafik Hasil Simulasi Biaya terhadap Emisi dengan Firefly Algorithm

\section{Hubungan Biaya Bahan Bakar dan Emisi dengan} Menggunakan Metode Firefly Algorthm

Pada sub-bab ini, akan dijelaskan hasil simulasi untuk total biaya dan total emisi selama 4 jam dengan 5 kondisi yang berbeda yang disesuaikan dengan tingkat prioritas dari objek yang diminimalkan. Hasil simulasi untuk total biaya dan total emisi selama 4 jam dengan menggunakan metode Firefly Algorthm dapat dilihat pada Tabel 6.

Tabel 6.

Hasil Simulasi Total Biaya dan Total Emisi Selama 4 Jam Menggunakan Particle Swarm Optimation.

\begin{tabular}{ccc}
\hline \hline Kondisi & Biaya (Rupiah/4jam) & Emisi NO $_{\mathbf{2}}(\boldsymbol{\%})$ \\
\hline 1 & 18.216 .288 .250 & 8.192 .906 .672 \\
2 & 18.257 .877 .005 & 8.015 .324 .665 \\
3 & 18.360 .863 .935 & 7.962 .234 .620 \\
4 & 18.517 .976 .626 & 7.868 .965 .431 \\
5 & 20.685 .607 .923 & 7.484 .509 .831 \\
\hline \hline
\end{tabular}

Tabel 6 adalah hasil simulasi total biaya dan total emisi selama 4 jam dengan 5 kondisi yang berbeda sesuai dengan tingkat prioritas dari objek yang diminimalkan. Pada kondisi pertama yang di pertimbangkan hanya biaya pembangkitan dengan total 18.216.288.249,58 Rp / 4 Jam dan dengan total emisi 8.192.906.672 gram/4jam. Pada kondisi kedua yang diprioritaskan lebih adalah biaya pembangkitan dari pada emisi dengan total biaya pembangkitan 18.257.877.005,29 $\mathrm{Rp} / 4$ jam dengan total emisi 8.015.324.665.

Pada kondisi ketiga total biaya pembangkitan dan total emisi sama-sama diprioritaskan, keduanya memiliki bobot yang sama dengan total biaya pembangkitan sebesar 18.360.863.935 Rp/4jam dan total emisi dengan total emisi sebesar 7.962.234.620 gram/4jam. Pada kondisi keempat nilai emisi lebih diprioritaskan untuk di minimalkan dari pada biaya pembangkitan dengan total biaya pembangkitan sebesar 18.517.976.626,02 Rp/4jam dan total emisi dengan total emisi sebesar 7.868.965.431 gram/4jam. Pada kondisi kelima nilai emisi paling diprioritaskan dan nilai pembangkitan tidak diperhitungkan sama sekali dengan total biaya pembangkitan sebesar 20.685.607.922,52 Rp/4jam dan total emisi dengan total emisi sebesar 7.484.509.831 gram/4jam.

Sedangkan untuk kurva yang dibentuk dari biaya dan bahan bakar $\mathrm{NO}_{2}$ pada masing masing kondisi tiap pembobotan masing-masing dengan metode Particle Swarm Optimation dapat dilihat pada Gambar 4. Berdasarkan hasil simulasi dan kurva perbandingan antara metode Cuckoo Optimization Algorithm, dan metode Firefly Algorithm metode PSO ini lebih optimal dibandingkan kedua metode tersebut.

\section{Grafik Biaya Terhadap Emisi}

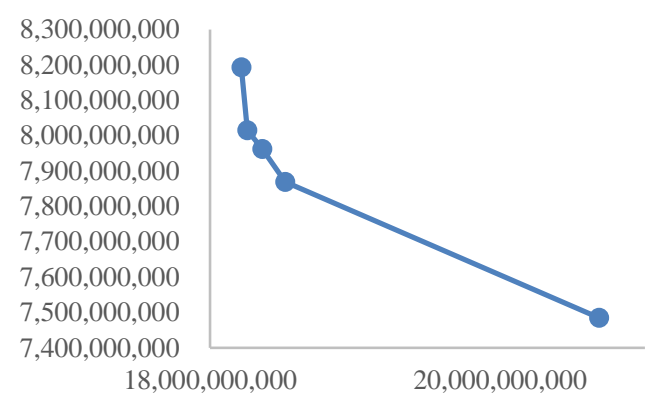

Gambar 4. Grafik Hasil Simulasi Biaya terhadap Emisi dengan Firefly Algorithm

\section{B. Perbandingan Biaya Bahan Bakar dan Emisi Hasil Economic Emission Dispatch}

Dari data yang diperoleh pada hasil program, menunjukkan bahwa multi objektif Economic Emission Dispatch dapat mengurangi emisi gas $\mathrm{NO}_{2}$ (Karbon Dioksida), namun semakin berkurangnya emisi , biaya bahan bakar akan semakin naik. Masing-masing hasil prosentase pengurangan emisi menggunakan metode COA, FA dan PSO dapat dilihat pada Tabel 7, Tabel 8, dan Tabel 9.

Tabel 7.

Pengurangan Emisi dengan Cuckoo Optimization Algorithm

\begin{tabular}{|c|c|c|c|c|c|c|}
\hline \multicolumn{2}{|c|}{ Kondisi } & \multirow{2}{*}{$\begin{array}{l}\text { Biaya } \\
\text { (Juta/ } \\
\text { 4jam) }\end{array}$} & \multirow{2}{*}{$\begin{array}{c}\text { Emisi } \\
\mathrm{NO}_{2}(\%)\end{array}$} & \multirow{2}{*}{$\begin{array}{c}\text { Emisi } \\
\text { Yang } \\
\text { Dapat } \\
\text { Dikurangi }\end{array}$} & \multirow{2}{*}{$\begin{array}{c}\text { Penambahan } \\
\text { Emisi (\%) }\end{array}$} & \multirow{2}{*}{$\begin{array}{c}\text { Penambahan } \\
\text { Biaya }(\%)\end{array}$} \\
\hline We & Ws & & & & & \\
\hline 1 & 0 & $18.645,85$ & $8.577,29$ & 0 & 0 & 0 \\
\hline $\begin{array}{c}0.7 \\
5\end{array}$ & $\begin{array}{c}0.2 \\
5\end{array}$ & $18.824,21$ & $8.489,37$ & 87,92 & 1,02 & 0.95 \\
\hline 0.5 & 0.5 & $18.845,61$ & $8.389,94$ & 187,35 & 2,18 & 1,05 \\
\hline $\begin{array}{c}0.2 \\
5\end{array}$ & $\begin{array}{c}0.7 \\
5\end{array}$ & $18.940,40$ & $7.961,17$ & 616,12 & 7,18 & 1,55 \\
\hline 0 & 1 & $20.590,91$ & $7.761,93$ & 815,36 & 9,5 & 9,44 \\
\hline
\end{tabular}


Tabel 8.

Pengurangan Emisi dengan Metode Firefly

\begin{tabular}{ccccccc}
\hline \hline \multicolumn{2}{c}{ Kondisi } & $\begin{array}{c}\text { Biaya } \\
\text { (Juta/ }\end{array}$ & $\begin{array}{c}\text { Emisi } \\
\mathbf{N O}_{2}(\%)\end{array}$ & $\begin{array}{c}\text { Emisi Yang } \\
\text { Dapat } \\
\text { Dikurangi }\end{array}$ & $\begin{array}{c}\text { Penambahan } \\
\text { Emisi (\%) }\end{array}$ & $\begin{array}{c}\text { Penambahan } \\
\text { Biaya (\%) }\end{array}$ \\
Wc & Ws & 4jam) & & & & 0 \\
\hline 1 & 0 & $19.176,04$ & $8.677,88$ & 0 & 0 & 0,25 \\
0.7 & 0.25 & $19.233,58$ & $8.628,48$ & 49,4 & 0,57 & 0,39 \\
5 & 0.5 & $19.251,39$ & $8.523,03$ & 154,85 & 1,78 & 1,89 \\
0.2 & 0.75 & $19.539,17$ & $8.480,26$ & 197,62 & 2,28 & 5,24 \\
\hline 5 & 1 & $20.181,37$ & $8.294,55$ & 383,33 & 4,42 & \\
\hline \hline
\end{tabular}

Tabel 9.

Pengurangan Emisi dengan Metode Particle Swarm Optimation

\begin{tabular}{|c|c|c|c|c|c|c|}
\hline Wc & Ws & $\begin{array}{l}\text { Biaya } \\
\text { (Juta/ } \\
\text { 4jam) }\end{array}$ & $\begin{array}{c}\text { Emisi } \\
\mathrm{NO}_{2} \\
(\%)\end{array}$ & $\begin{array}{c}\text { Emisi } \\
\text { Yang } \\
\text { Dapat } \\
\text { Dikurangi }\end{array}$ & $\begin{array}{c}\text { Penambaha } \\
\text { n Emisi } \\
(\%)\end{array}$ & $\begin{array}{c}\text { Penambaha } \\
\text { n Biaya } \\
(\%)\end{array}$ \\
\hline 1 & 0 & $\begin{array}{c}18.216,2 \\
9\end{array}$ & $\begin{array}{c}8.192,9 \\
0\end{array}$ & 0 & 0 & 0 \\
\hline $\begin{array}{c}0.7 \\
5\end{array}$ & $\begin{array}{c}0.2 \\
5\end{array}$ & $\begin{array}{c}18.257,8 \\
8\end{array}$ & $\begin{array}{c}8.015,3 \\
2\end{array}$ & 177,58 & 2,16 & 0,23 \\
\hline 0.5 & 0.5 & $\begin{array}{c}18.360,8 \\
6\end{array}$ & $\begin{array}{c}7.962,2 \\
3\end{array}$ & 230,67 & 2,81 & 0,79 \\
\hline $\begin{array}{c}0.2 \\
5\end{array}$ & $\begin{array}{c}0.7 \\
5\end{array}$ & $\begin{array}{c}18.517,9 \\
8\end{array}$ & $\begin{array}{c}7.868,9 \\
6\end{array}$ & 323,94 & 3,95 & 1,65 \\
\hline 0 & 1 & $\begin{array}{c}20.685,6 \\
1\end{array}$ & $\begin{array}{c}7.282,5 \\
1\end{array}$ & 708,39 & 8,64 & 13,55 \\
\hline
\end{tabular}

\section{KESIMPULAN}

Berdas Berdasarkan hasil simulasi dan analisis Economic Dispatch Emission menggunakan Cuckoo Search Algorithm maka pada Penelitian ini didapat kesimpulan sebagai berikut:

1. Cuckcoo Optimization Algorithm dapat digunakan menyelesaikan permasalahan ED Economic EmissionDisptah

2. Hasil simulasi menunjukkan bahwa semakin tinggi nilai emisi maka semakin rendah biaya pembangkitan.

3. Hasil simulasi dengan data yang sama dibanding metode Cuckoo Optimization Algortihm dengan Particle Swarm Optimation lebih optimal menggunakan PSO jika dilihat dari total rata-rata masing-masing kondisi yaitu sebesar 18.807,72 Juta/4 Jam dan total emisi rata 7864,38 untuk PSO dan 19169.39 Rp/Jam dan 8235.94 gram/Jam prioritas yang berbeda.

4. Hasil Simulasi dengan data yang sama dibanding metode Cuckoo Optimization Algortihm dengan Firefly lebih optimal menggunakan Cuckoo. Jika dilihat dari total rata-rata masing-masing kondisi yaitu sebesar . 8.520,84 gram/Jam untuk total emisi dan $19.476,31 \mathrm{Rp} / \mathrm{Jam}$ untuk total biaya pembangkitan

\section{DAFTAR PUSTAKA}

[1] A.Farhat and M.E.EL-Hawary,'Bacterial Foraging Algorithm For Optimum Economic-Emission Dispatch " Power System IEEE Transaction978-1-45577-4040-8/11/2011/economic dispatch algorithm,"

[2] X. S. Yang and S. Deb, "Cuckoo search via Lévy flights," IEEE, vol. NaBIC 2009, no. In Nature \& Biologically Inspired Computing, pp. 210 214, 2009.

[3] J.H.Talaq, F. El-Hawary and M.E. El-Hawary,"A Summary of enviromental/ economic dispatch algorithm"Transaction978-1-45774040-8/11/2012

[4] Hadi Saadat, "Power System Analysis," WCB McGraw-Hil, New York, 1999

[5] El- Keib AA, Ma H, JL Hart, "Economic Dispatch in viewof the Clean Air Act of 1990," IEEE Trans Power Syst, Vol.9, No. 2, pp.972-978, 1994. 